\title{
Fission track age of the Kt-7 Tuff in the Miocene Kubota Formation in the eastern Tanagura area, Northeast Japan
}

\author{
Masaki TAKAHASHI ${ }^{1}$, Hideki IwANO ${ }^{2}$, Yukio YANAGISAWA ${ }^{1}$ and Hiroki HAYASHI ${ }^{3}$ \\ Masaki TAKAHASHI, Hideki IwANo, Yukio YANAGISAWA and Hiroki HAYASHI (2001) Fission track \\ age of the Kt-7 Tuff in the Miocene Kubota Formation in the eastern Tanagura area, Northeast \\ Japan. Bull. Geol. Surv. Japan, vol. 52 (6/7), p. 291-301, 6 figs, 1 table.
}

\begin{abstract}
The fission track dating was applied for the Kt-7 Tuff, interbedded in the uppermost part of the Miocene Kubota Formation in the eastern Tanagura area, Northeast Japan. The fission track age of the $\mathrm{Kt}-7$ Tuff $(10.6 \pm 0.3 \mathrm{Ma}$; $1 \sigma$ error) is almost equal to the $\mathrm{K}$-Ar and fission track ages of the Kt-1 Tuff, interbedded in the lowest part of the Kubota Formation. These radiometric ages show good agreement with the previously established calcareous and siliceous microfossil biostratigraphy. The integrated stratigraphy based on microfossils as well as $\mathrm{K}$ - $\mathrm{Ar}$ and fission track ages indicate a high sedimentation rate of the Kubota Formation.
\end{abstract}

\section{Introduction}

Microfossil biostratigraphy is one of the most common and useful tool for age determination of marine sediments, although it indicates only stratigraphic relations. If we need a numerical age of strata based on yielded microfossils, we can estimate the age using a time scale, which is constructed by a combination of magneto-biostratigraphy and geomagnetic polarity time scale (GPTS). Therefore, the reliability of the time scale depends on the accuracy of the GPTS and validity of correlation between marine magnetic anomaly pattern (GPTS) and magnetostratigraphy. Recently Berggren et al. (1995) constructed a geologic time scale based on Cande and Kent's (1995) GPTS, although Baksi (1993), Wei (1995) and Takahashi and Danhara (1997) have pointed out serious problems on the GPTS. Therefore, it is obviously effective to integrate the chronology based on the radiometric dating with the magneto- and/or biostratigraphy. Some Neogene marine sequences in Japan interbed datable volcaniclastic layers, which have a great advantage for constructing a time scale (Takahashi and Oda, 1997).

A Miocene marine sequence is well exposed in the eastern Tanagura area, Northeast Japan (Fig. 1). This sequence is divided into the Akasaka and Kubota Formations (Otsuki, 1975). The Kubota Formation

\footnotetext{
Institute of Geoscience, GSJ

${ }^{2}$ Kyoto Fission-Track Co., Ltd. 44-4 Minami-Tajiricho, Kita-ku, Kyoto, 603-8832 Japan

${ }^{3}$ Institute of Geology and Paleontology, Graduate School of Science, Tohoku University. Aoba, Aramaki, Aobaku, Sendai, 980-8578 Japan
}

yields microfossils dominantly. Many previous works investigated the detailed biostratigraphy on this formation (Aita, 1988; Taketani and Aita, 1991; Shimamoto et al., 1998; Hayashi et al., 2000; Yanagisawa et al., 2000). Recently, Takahashi et al. (2001) first determined $\mathrm{K}-\mathrm{Ar}$ and fission track ages of the Kt-1 Tuff, interbedded in the lowest part of the Kubota Formation, however the age of the youngest limit of this marine sequence is unclear.

In this paper, we show brief introduction of the geology, litho- and biostratigraphy and newly obtained fission track age of the Kt-7 Tuff, interbedded in the uppermost part of the Kubota Formation. The stratigraphic relations between some important microfossil biohorizons and radiometric ages of two pyroclastic rocks are also discussed.

\section{Geology and stratigraphy}

The eastern Tanagura area is situated on the southern part of Northeast Japan (Fig. 1). The Miocene marine sequence unconformably overlies the preNeogene granitic and metamorphic rocks along the eastern margin, and is covered by a Pliocene conglomerate of the Nikogi Formation horizontally. The Miocene sedimentary rocks are gently tilted northwesterly, but they steeply incline easterly along the western marginal thrust fault (Shimamoto et al., 1998).

The Miocene sequence is more than $500 \mathrm{~m}$ in thickness and divided into the following two formations

Keywords: fission track age, biostratigraphy, integrated stratigraphy, Miocene, Kubota Formation, Northeast Japan 


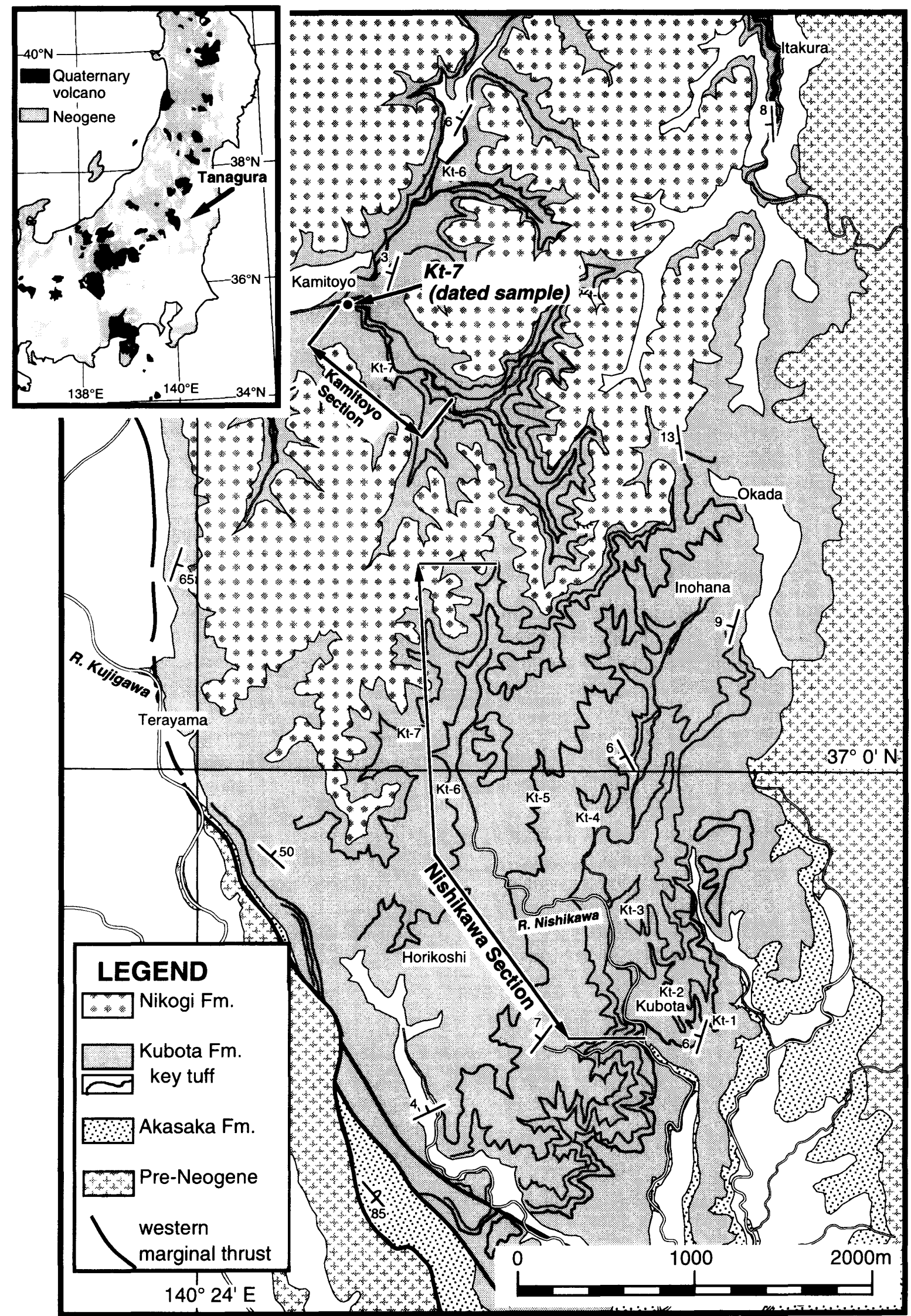

Fig. 1 Sample location on the geological map of the Miocene marine sequence of the Kubota Formation, distributed in the eastern Tanagura area, Northeast Japan (modified from Shimamoto et al., 1998). Index map is modified from Yamada et al. (1990). 
(Otsuki, 1975). The Akasaka Formation is composed of conglomerate, medium- to coarse-grained sandstone and siltstone. Cross-bedding structure is often observed throughout this formation. Marine molluscs are yielded, indicating a shallow sedimentary environment. Benthic foraminifers, which suggests an inner sublittoral zone environment (shallower than $50 \mathrm{~m}$ ), are reported from the Akasaka Formation (Shimamoto et al., 1998).

In contrast, fine-grained sandstone and siltstone with frequent intercalation of thin volcaniclastic layers dominate the Kubota Formation, which conformably covers the Akasaka Formation. More than 20 tuff beds, interbedded in this formation, are all felsic. The volcaniclastic layers of the Kt-1 through $\mathrm{Kt}-1 \mathrm{C}$ Tuffs are alternating beds of coarse-grained biotiterich volcaniclastics and silty tuff layers. Only the Kt7 Tuff consists of pumice tuff, while the rest (Kt-2 through Kt6A) are all fine-grained thin tuff beds (Takahashi et al., 2001).

Shimamoto et al. (1998) concluded that most of the Kubota Formation is correlative to the planktonic foraminiferal zone N.16 of Blow (1969) or calcareous nannofossil zones CN6 to CN7 of Okada and Bukry (1980). Recently Hayashi et al. (2000) re-investigated the planktonic foraminiferal biostratigraphy. They recognized a key species of Neogloboquadrina acostaensis, whose first occurrence (FO) defines the lower limit of zone N. 16, in the lowest part of the Kubota Formation (Fig. 2). Calcareous nannofossil key species of Catinaster coalitus, whose FO defines the base of CN6, and Catinaster calyculus, whose FO defines the base of $\mathrm{CN} 7$, were also reported (Shimamoto et al., 1998; Fig. 2). Radiolaria continuously occurred from the middle part of the Kubota Formation. Shimamoto et al. (1998) concluded that the middle part of the Kubota Formation is correlative to the Lychnocanoma magnacornuta Zone of Motoyama and Maruyama (1998). According to Yanagisawa et al. (2000), the stratigraphic interval from the Kt-1 to the middle of the $\mathrm{Kt}-4 \mathrm{~B}$ and $\mathrm{Kt}-4 \mathrm{C}$ tuff levels is correlative to the Thalassiosira yabei Zone (NPD 5C) of Yanagisawa and Akiba (1998), because of the occurrence of both Denticulopsis simonsenii and Denticulopsis vulgaris and the absence of Denticulopsis dimorpha and Denticulopsis praedimorpha. The quite rare occurrence of Denticulopsis hustedtii suggests that the lower part of the Kubota Formation is younger than the acme and last common occurrence biohorizons of D. hustedtii (D55.8: 10.1 Ma), that is, the upper part of the T. yabei Zone. A few occurrences of some important diatom key species also suggest that the upper part of the Kubota Formation (around the Kt-6 Tuff level) also can be correlated to the T. yabei Zone (NPD 5C).

Takahashi et al. (2001) recently determined $\mathrm{K}-\mathrm{Ar}$ and fission track ages for the Kt-1 Tuff. As the K-Ar age $(10.6 \pm 0.2 \mathrm{Ma} ; 1 \sigma$ error $)$ and fission track age $(10.7 \pm 0.2 \mathrm{Ma})$ of the Kt-1 Tuff coincide each other, Takahashi et al. (2001) concluded that these ages represent an age of the Kt-1 pyroclastics eruption.

\section{Fission track dating}

Fission track dating was performed for pumiceous tuff of the lowest part of the Kt-7 Tuff, interbedded in the uppermost part of the Kubota Formation. The Kt-7 Tuff is $5 \mathrm{~m}$-thick, very fine to clayey tuff as shown in Fig. 3. Only the lowest part is pumiceous, and middle part is characterized by thin-bedded very fine tuff and clayey hard tuff set. As the Kt-7 Tuff contains neither sufficient biotite nor hornblende which are suitable for conventional $\mathrm{K}$-Ar dating, we attempted to date it by the fission track method using zircon. About $3 \mathrm{~kg}$ of tuff sample was collected from the lowest part of the Kt-7 Tuff (Fig. 3).

Sufficient zircon grains were concentrated by sieving, panning, and standard magnetic and heavy liquid separating techniques. Two types of zircon crystals from this tuff sample were recognized. One is clear, reddish, euhedral and having lower spontaneous track density $(\rho s)$. The other is dark, brownish, subhedral and having higher $\rho s$. The former group, approximately $60 \%$ of the separated grains, can be regarded as an essential ones, and then we measured 100 zircon grains for this group. Seven zircon grains belonging to the latter group, regarded as reworked ones, were also measured as reference.

Fission track dating was carried out using the external detector method, which is applied to internal (polished) surfaces of zircon grains (ED1 methods: Gleadow, 1981). Ages were calculated following the zeta approach (Hurford, 1990). The experimental procedures and system calibrations were detailed elsewhere (see Danhara et al., 1991; Iwano and Danhara, 1997). The results are listed in Table 1.

\section{Results and discussion}

Fission track data is shown in Fig. 4. Based on the grain-age histogram and the correlations between spontaneous track counts $(N s)$ and induced track counts $(\mathrm{Ni})$ as well as between $\rho s$ and induced track density $(\rho i)$ in Fig. 4, we can obviously distinguish the younger age component from the older age component, which correspond to the above-mentioned reddish and euhedral grains and the brownish and rounded grains, respectively. The resulting ages were calculated to be $10.6 \pm 0.3 \mathrm{Ma}$ ( $1 \sigma$ error) for the younger and $48.4 \pm 3.0 \mathrm{Ma}$ for the older. Fission track data for the younger group failed the $\chi^{2}$-test (Galbraith, 1981) at the 5\% significance level. However, this is probably explained by the failing tendency of the $\chi^{2}$-test in ED1 data that are affected by addi- 


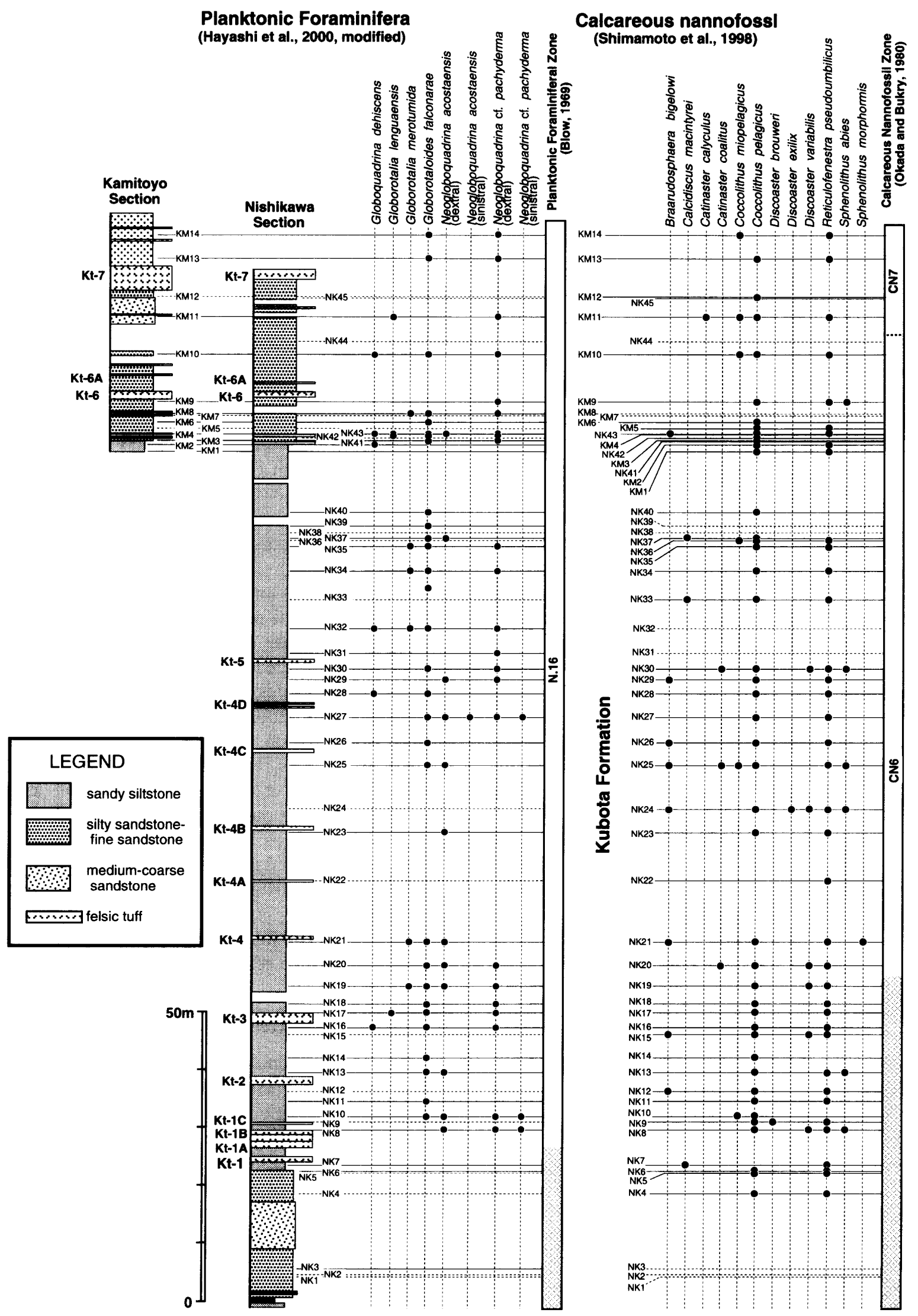

Fig. 2 The stratigraphic distributions of selected planktonic foraminiferal (Hayashi et al., 2000), calcareous nannofossil and radiolarian (Shimamoto et al., 1998) and diatom species (Yanagisawa et al., 2000) in the Kubota Formation. Radiometric ages of the Kt-1 Tuff (Takahashi et al., 2001) and Kt-7 (this work), as well as estimated ages of some important planktonic microfossil biohorizons, are also indicated. 
FT age of the Kt-7 Tuff in the Tanagura area, NE Japan (TAKAHASHI et al.)

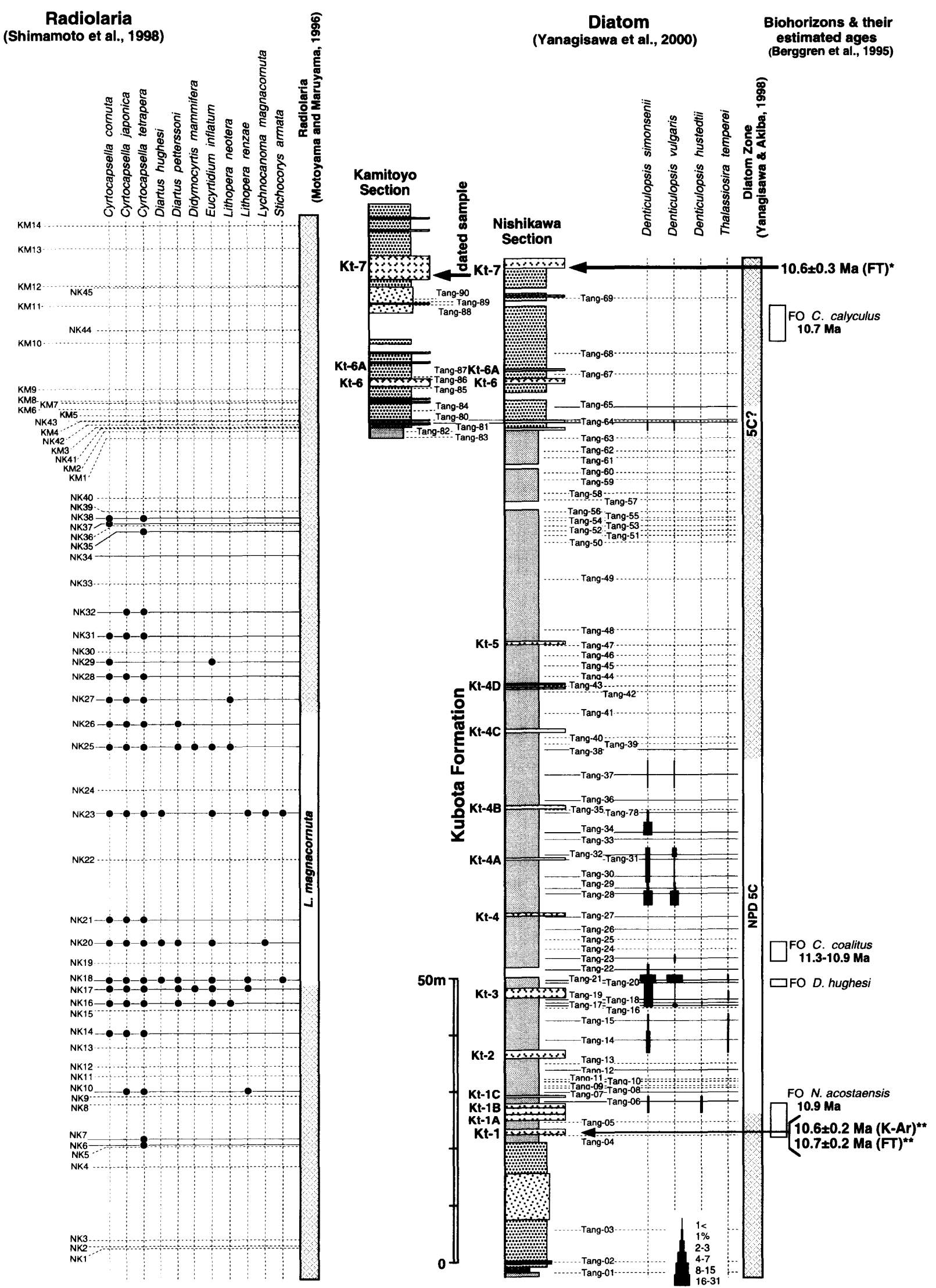

Fig. 2 (Continued) 


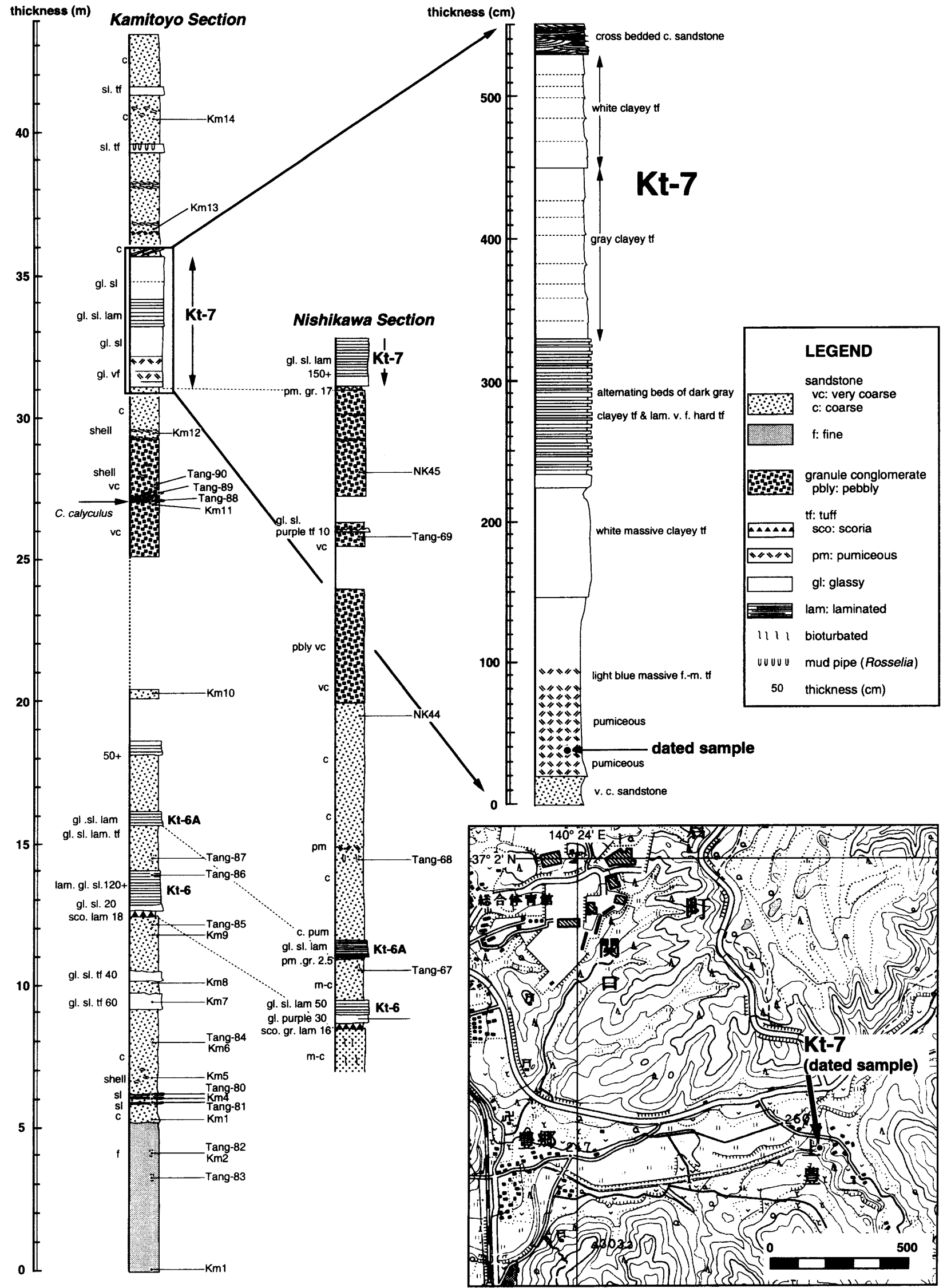

Fig. 3 The columnar sections of the upper part of the Kubota Formation. The stratigraphic position of dated sample is indicated on the detailed column of the $\mathrm{Kt}^{-7}$ Tuff. The location of tuff sample is also shown on the geographical map (topographic map: "Tanagura", scale 1/25,000 by the Geographical Survey Institute). 
Table 1 Fission track data of zircons from the Kt-7 Tuff in the uppermost part of the Kubota Formation. Two types of zircon crystals were recognized. One is clear, reddish, euhedral and having lower spontaneous track density ( $\rho s)$. The other is dark, brownish, subhedral and having higher $\rho s$. The former group, approximately $60 \%$ of the separated grains, can be regarded as an essential ones, and then we measured 100 zircon grains for this group. Seven zircon grains belonging to the latter group, regarded as reworked ones, were also measured.

\begin{tabular}{|c|c|c|c|c|c|c|c|c|c|c|c|c|}
\hline \multirow{3}{*}{$\begin{array}{l}\text { Sampe } \\
\text { code }\end{array}$} & \multirow{3}{*}{$\begin{array}{l}\text { No. of } \\
\text { crystals }\end{array}$} & \multicolumn{2}{|c|}{ Spontaneous } & \multicolumn{2}{|c|}{ Induced } & \multirow{3}{*}{$\begin{array}{c}P(\chi 2) \\
(\%)\end{array}$} & \multicolumn{2}{|c|}{ Dosimeter } & \multirow[t]{3}{*}{$r$} & \multirow{3}{*}{$\begin{array}{c}\text { U- } \\
\text { content } \\
\text { (ppm) }\end{array}$} & \multirow{3}{*}{$\begin{array}{l}\text { Age } \\
( \pm 1 \sigma) \\
(\mathrm{Ma})\end{array}$} & \multirow[t]{3}{*}{ Method } \\
\hline & & $\rho s$ & $(N s)$ & $\rho i$ & $(N i)$ & & $\rho d$ & $(N d)$ & & & & \\
\hline & & \multicolumn{2}{|c|}{$\left(10^{6} \mathrm{~cm}^{-2}\right)$} & \multicolumn{2}{|c|}{$\left(10^{6} \mathrm{~cm}^{-2}\right)$} & & \multicolumn{2}{|c|}{$\left(10^{4} \mathrm{~cm}^{-2}\right)$} & & & & \\
\hline Kt-7(essential) & 100 & 1.59 & $(4286)$ & 2.14 & (5779) & 2 & 8.130 & (2498) & 0.902 & 210 & $10.6 \pm 0.3$ & ED1 \\
\hline Kt-7(detrital) & 7 & 6.53 & (1352) & 1.92 & (398) & 6 & 8.130 & (2498) & 0.878 & 180 & $48.4 \pm 3.0$ & ED1 \\
\hline
\end{tabular}

(1) $\rho$ and $N$ are the density and total number of fission tracks counted, respectively.

(2) Analyses were made by the external detector method using a geometry factor of 0.5 for $2 \pi / 4 \pi$ (ED1).

(3) Ages were calculated using a dosimeter glass SRM612 and age calibration factors $\boldsymbol{\xi}$ (ED1) $=352 \pm 3$ (Iwano and Danhara, 1997).

(4) $P\left(\chi^{2}\right)$ is the probability of obtaining the $\chi^{2}$-value for $\nu$ degrees of freedom (where $\nu=$ number of crystals -1$)$.

(5) $r$ is the correlation coefficient between $\rho s$ and $\rho i$.

(6) Samples were irradiated using TRIGA MARK II nuclear reactor of St. Paul's University (Rikkyo Daigaku), Japan.

tional variation other than the Poisson variation in track counts. Danhara et al. (1991) pointed out that the main source of the non-Poisson variation in ED1 is the difference in uranium contents above and below the observed internal surfaces. If we omitted two more grains with the oldest grain-age from the younger group, in spite of the euhedral shape and reddish color crystals, the re-calculate age of $10.5 \pm 0.3$ Ma using the rest 98 grains shows no significantly change although the data passed the $\chi^{2}$-test. Therefore, we adopted here the obtained age of $10.6 \pm 0.3 \mathrm{Ma}$ calculated from all of 100 grains as an eruption age of the Kt-7 pyroclastics in this report.

The fission track age of $10.6 \pm 0.3 \mathrm{Ma}$ shows almost the same ages of the $\mathrm{K}-\mathrm{Ar}$ as well as fission track age of the Kt-1 pyroclastics, intebedded about $200 \mathrm{~m}$ below the Kt-7 Tuff. Thus the high sediment accumulation rate for the Kubota Formation is suggested (Fig. 5).

Hayashi et al. (2000) recognized Neogloboquadrina acostaensis at almost the same horizon as the dated $\mathrm{Kt}$ -1 Tuff (Fig. 2). The FO of $N$. acostaensis defines the base of zone N. 16, and is estimated at $10.9 \mathrm{Ma}$ (Berggren et al., 1995). Therefore, the age of the Kt-1 Tuff (10.6-10.7 Ma) is biostratigraphically constrained to be $10.9 \mathrm{Ma}$ or younger. Thus the stratigraphic relation between the planktonic foraminiferal biostratigraphy and obtained radiometric ages of the $\mathrm{Kt}-1$ Tuff is consistent (Fig. 5).

As for the calcareous nannofossil biostratigraphy, three important biohorizons were recognized by Shimamoto et al. (1998). The FO of Catinaster coalitus, which defines the $\mathrm{CN} 5 \mathrm{~b} / \mathrm{CN} 6$ boundary and is estimated at 11.3-10.9 Ma (Berggren et al., 1995), was recognized at the middle level between the $\mathrm{Kt}-3$ and $\mathrm{Kt}-4$ tuff layers, about $30 \mathrm{~m}$ above the $\mathrm{Kt}-1$. The FO of Catinaster calyculus defines the base of $\mathrm{CN} 7$ and is estimated at $10.7 \mathrm{Ma}$ (Berggren et al., 1995). This biohorizon was reported at the upper part of the Kubota Formation. The last occurrence (LO) of Coccolithus miopelagicus (estimated at $11.0-10.8 \mathrm{Ma}$ ) is located at the uppermost part of the Kubota Formation, about $10 \mathrm{~m}$ below the Kt-7 pyroclastics $(10.6 \pm 0.3$ $\mathrm{Ma}$ ). Thus the estimated ages of each biohorizon almost coincide with the radiometric ages of the $\mathrm{Kt}-1$ and Kt-7 tuff layers. These chronostratigraphic ages as well as biostratigraphic age-estimations strongly suggest that about $200 \mathrm{~m}$-thick marine sediments of the Kubota Formation may be deposited during a very short time interval (the error of the radiometric ages; ca. 0.4 m.y.). Thus we can estimate a high sedimentation rate $(>25.5 \mathrm{~cm} / 1000 \mathrm{yr}$.) based on the radiometric ages of two tuff layers when we adopt $1 \sigma$ error for each age.

\section{Conclusion}

The fission track dating was applied for the Kt-7 Tuff, interbedded in the uppermost part of the Miocene Kubota Formation in the eastern Tanagura area, Northeast Japan. The fission track age of the Kt-7 pumice tuff $(10.6 \pm 0.3 \mathrm{Ma} ; 1 \sigma$ error $)$ shows almost same age to the $\mathrm{K}-\mathrm{Ar}$ and fission track ages of the Kt-1 Tuff, interbedded in the lowest part of the 


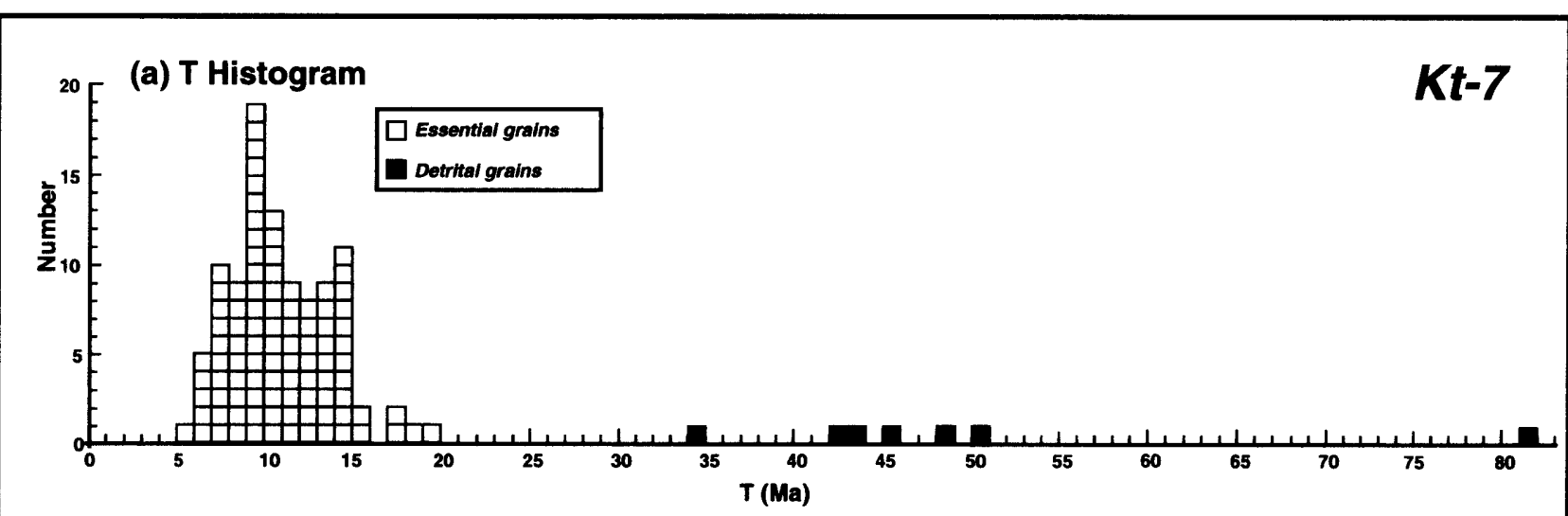

(b) Ns-Ni correlation

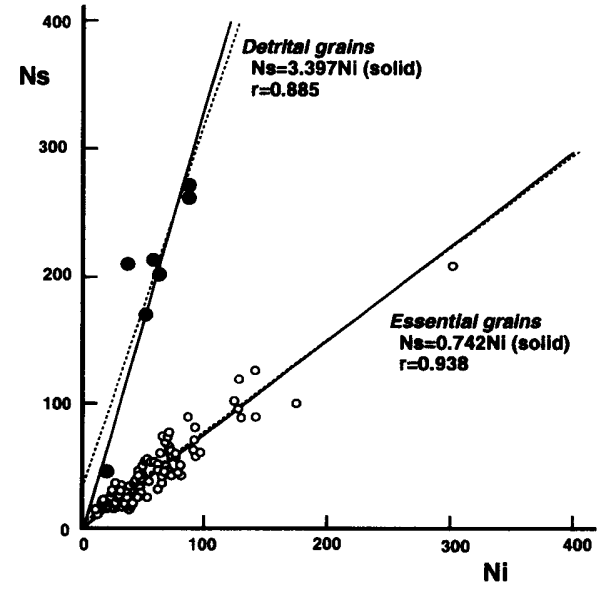

(c) $\rho_{\mathbf{S}-} \rho_{\text {i correlation }}$

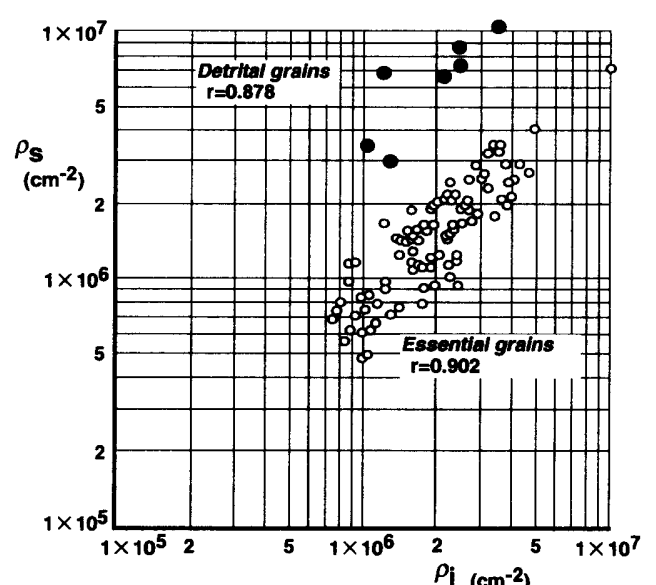

Fig. 4 Grain-by-grain plots of fission track data for zircon from the Kt-7 Tuff using the external detector method applied to the internal surface (ED1). (a) Histograms of grain-age, (b) correlation of spontaneous track counts $(N s)$ and induced track counts $(\mathrm{Ni})$, and (c) correlation of spontaneous track density ( $\rho s)$ and induced track density $(\rho i)$ are given. Statistical values of correlation coefficient $(\mathrm{r})$ is also indicated. The grain-age distribution and linearity of $N s / N i$ and $\rho s / \rho i$ correlation demonstrate that the Kt- 7 Tuff zircon has a single age population after exclusion of seven contaminated detrital (older) grains. 


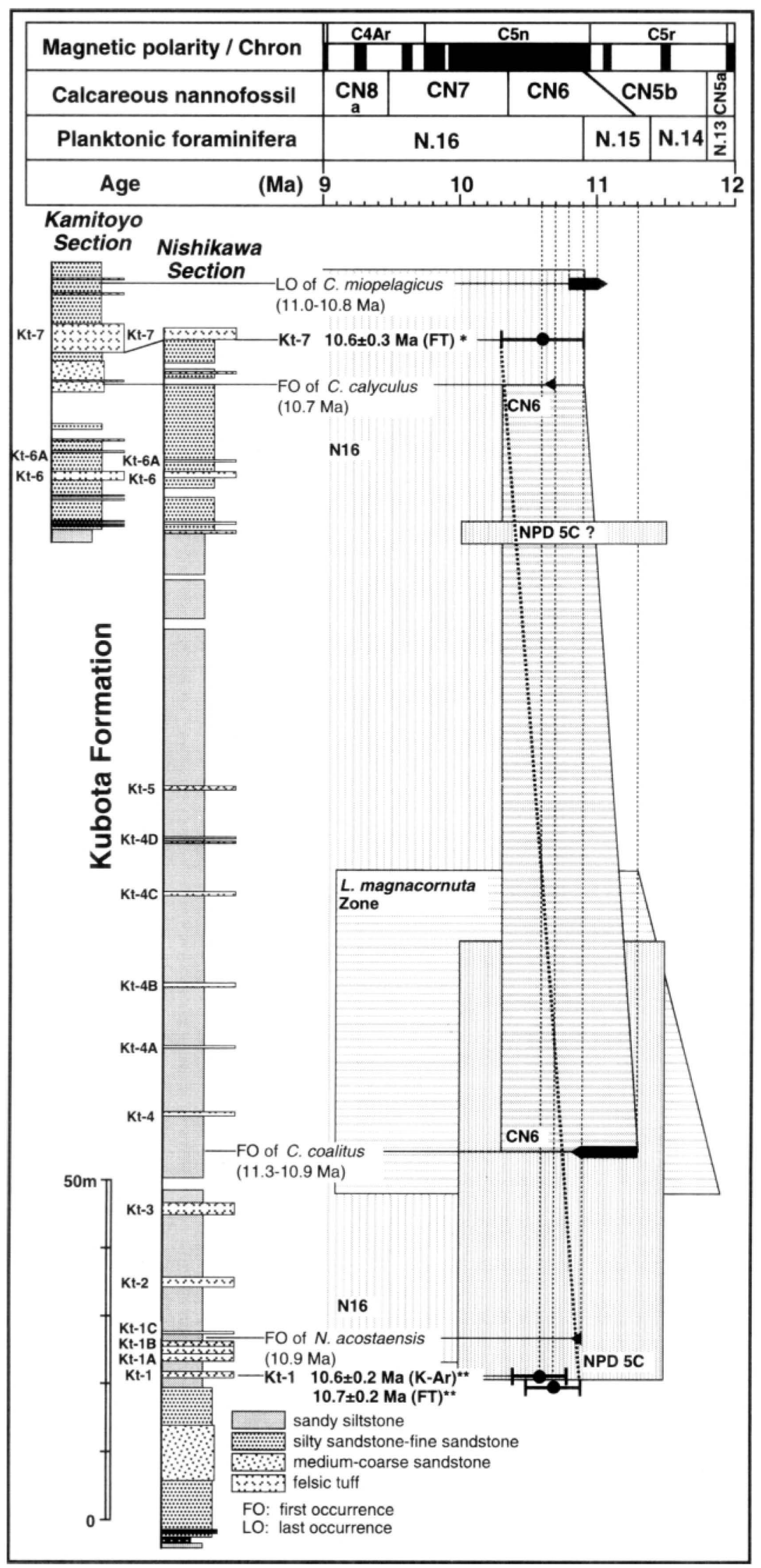

Fig. 5 Stratigraphic relationship between the dated tuff and biostratigraphic zones (included some important biohorizons). The integrated stratigraphic analysis revealed the high sedimentation rate of the Miocene marine sequence of the Kubota Formation. 
Kubota Formation. These radiometric ages show good agreement with the previously established calcareous and siliceous microfossil biostratigraphy, and suggest a high sedimentation rate of the Kubota Formation.

Acknowledgments: We are grateful to Tomoaki Sumii of the Institute of Geoscience, AIST, for his critical reading of the manuscript and constructive advice. We thank Tohru Danhara of Kyoto FissionTrack Co., Ltd. and Toji Numata of FAPIG Radiation Research Laboratory, Ltd. for their help with neutron irradiation at St. Paul's (Rikkyo) University reactor. This work has been realized under the working group of the Integrated Stratigraphy of Miocene Sequence: Miocene from Japan, which is under the auspices of the Subcommission on Geochronology, International Commission on Stratigraphy of the IUGS. In this context, the long-standing collaboration with Dr. G. S. Odin of the Pierre et Marie Curie University (Paris) has been especially helpful.

\section{References}

Aita, Y. (1988) Neogene planktonic foraminifera from the Kubota Formation, Tanagura area, Northeast Honshu, Japan. Bull. Fukushima Museum, (2), 13-27.*

Baksi, A. K. (1993) A geomagnetic polarity time scale for the period $0-17 \mathrm{Ma}$, based on ${ }^{40} \mathrm{Ar}-{ }^{39} \mathrm{Ar}$ plateau ages for selected field reversals. Geophys. Res. Lett., 20, 1607-1610.

Berggren, W. A., Kent, D. V., Swisher, C.C. III and Aubry, M.-P. (1995) A revised Cenozoic geochronology and chronostratigraphy, In Berggren, W. A., et al., eds., Geochronology, time scales and global stratigraphic correlation, SEPM Special Pub., 54, 129-212.

Blow, W.H. (1969) Late Miocene to Recent planktonic foraminiferal biostratigraphy. In Brönnimann, P. and Renz, H. H., eds., Proceedings of the First International Conference on Planktonic Microfossils, Geneva 1967, 1, E. J. Brill, Leiden, 199-422.

Cande, S. C. and Kent, D. V. (1995) Revised calibration of the geomagnetic polarity time scale for the Late Cretaceous and Cenozoic. Jour. Geophys. Res., 100, 6093-6095.

Danhara, T., Kasuya, M. and Yamashita, T. (1991) Fission-track age calibration using internal and external surfaces of zircon. Jour. Geol. Soc. Japan, 97, 977-985.

Galbraith, R. F. (1981) On statistical models for fission track counts. Jour. Math. Geol., 13, 471-478.

Gleadow, A. J. W. (1981) Fission-track dating method: what are the real alternative? Nucl.
Track Detection, 2, 105-117.

Hayashi, H., Yamaguchi, T. and Takahashi, M. (2000) Planktonic foraminiferal biostratigraphy of the Miocene Kubota Formation in the Higashitanagura area, Fukushima Prefecture. Abstr. 2000 Annual Meet., Paleontol. Soc. Japan, 31.**

Hurford, A. J. (1990) Standardization of fission track dating calibration: Recommendation by the Fission Track Working Group of the I.U. G.S. Subcommission on Geochronology. Chem. Geol. (Isotope Geosci. Sect.), 80, 171178.

Iwano, H. and Danhara, T. (1997) Zeta calibration of fission-track dating system using highresolution monitor and comparison of reported zeta values. Fission Track News Letters, (10), 11-20.*

Motoyama, I. and Maruyama, T. (1998) Neogene diatom and radiolarian biochronology for the middle-to-high latitudes of the Northwest Pacific region: Calibration to the Cande and Kent's geomagnetic polarity time scales (CK92 and CK95). Jour. Geol. Soc. Japan, 104, 171-183.*

Okada, H. and Bukry, D. (1980) Supplementary modification and introduction of code numbers to the low-latitude coccolith biostratigraphic zonation (Bukry, 1973, 1975). Mar. Micropaleontol., 5, 321-325.

Otsuki, K. (1975) Geology of the Tanakura shear zone and adjacent area. Contrib. Inst. Geol. Paleont., Tohoku Univ., (76), 1-71.*

Shimamoto, M., Hayashi, H., Suzuki, N., Tanaka, Y. and Saito, T. (1998) Lithostratigraphy and microfossil biochronology of Neogene sediments in the eastern Tanagura area, Fukushima Prefecture, Northeast Japan. Jour. Geol. Soc. Japan, 104, 296-312.*

Takahashi, M. and Danhara, T. (1997) Fission track age of Miocene $\mathrm{Kn}-3$ Tuff in central Japan: Towards better age-control on magneto-biostratigraphic time scale. Jour. Geomag. Geoelectr., 49, 89-99.

Takahashi, M. and Oda, M. (1997) Geology, tectonics, and integrated stratigraphy potential of Japan. In Montanari, A. et al., eds., Miocene Stratigraphy: An Integrated Approach, (15), Elsevier, 187-202.

Takahashi, M., Hayashi, H., Danhara, T., Iwano, H. and Okada, T. (2001) K-Ar and fission track ages of the Kt-1 Tuff in the Miocene marine sequence in the Tanagura area, Northeast Japan. Japan. Assoc. Petrol. Technol., 66, 311-318.

Taketani, Y. and Aita, Y. (1991) Miocene radiolaria from the Kubota Formation, 
Tanagura area, Northeast Honshu, Japan. Bull. Fukushima Museum, (5) 31-51.*

Wei, W. (1995) Revised age calibration points for the geomagnetic polarity time scale. Geophys. Res. Lett., 22, 957-960.

Yamada, N., Saito, E. and Murata, Y. eds. (1990) Computer-generated Geologic Map of Japan. 1:2,000,000 Map Series, (22), Geological Survey of Japan.

Yanagisawa, Y. and Akiba, F. (1998) Refined Neogene diatom biostratigraphy for the northwest Pacific around Japan, with an introduction of code numbers for selected diatom biohorizons. Jour. Geol. Soc. Japan,
104, 395-414.

Yanagisawa, Y., Yamaguchi, T. and Hayashi, H. (2000) Diatom biostratigraphy of the Miocene Kubota Formation in the Higashitanagura area, Fukushima Prefecture. Abstr. 2000 Annual Meet., Paleontol. Soc. Japan, $29 .^{* *}$

* in Japanese with English abstract.

* in Japanese.

Received May 18, 2001

Accepted July 18, 2001

\title{
福島県東棚倉地域に分布する中新世海成層に挟在する $\mathrm{Kt}-7$ 凝灰岩の \\ フィッショントラック年代
}

高橋雅紀・岩野英樹・柳沢幸夫・林 広樹

\begin{abstract}
要旨
福島県東棚倉地域に分布する中新世海成層の久保田層最上部に挟在する軽石質凝圧岩 $(\mathrm{Kt}-1)$ 上り抽出

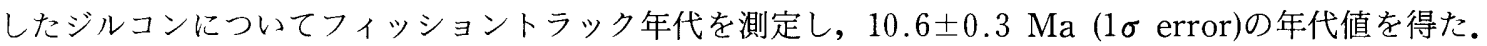
得られた年代值は，久保田層最下部で $\mathrm{Kt}-7$ 凝灰岩の抢よそ $200 \mathrm{~m}$ 下位に挟在する $\mathrm{Kt}-1$ 凝灭岩の $\mathrm{K}^{-}$ $\mathrm{Ar}$ 抢よびフィッショントラック年代に誤差範囲で一致する。これらの放射年代值は既存の浮遊性微化 石層序に基づく年代と調和的であることから，それぞれの火砕流堆積物の噴出年代を示すと判断される. 久保田層に打ける複合年代層序学的結果は, 久保田層の堆積速度が非常に大きかったことを示してい る.
\end{abstract}

